\title{
Why Did Americans Reject Compulsory Health Insurance after WWI? An Application of the Lifecycle Model
}

\author{
Stuart J. Wilson ${ }^{1}$ and J. C. Herbert Emery ${ }^{2}$ \\ ${ }^{1}$ Department of Economics, University of Regina, Regina, SK, Canada S4S OA2 \\ ${ }^{2}$ Department of Economics, University of Calgary, Calgary, AB, Canada T2N 1N4 \\ Correspondence should be addressed to Stuart J. Wilson, stuart.wilson@uregina.ca
}

Received 31 August 2011; Accepted 2 November 2011

Academic Editor: Thanasis Stengos

Copyright ( 2012 S. J. Wilson and J. C. H. Emery. This is an open access article distributed under the Creative Commons Attribution License, which permits unrestricted use, distribution, and reproduction in any medium, provided the original work is properly cited.

\begin{abstract}
Progressive reformers failed to gain support to implement compulsory health insurance in the US after WWI. Modeling results presented in this paper, using a lifecycle model with sickness risk and precautionary savings, support the conclusion that existing voluntary insurance plans were adequate and welfare-enhancing in the US, that compulsory health insurance as proposed would not be welfare-enhancing, and that Americans' preference to self-insure during most of their working lives was rational, utilitymaximizing behaviour.
\end{abstract}

\section{Introduction}

Americans have long debated the merits of compulsory or universal health insurance. Indeed, the Obama Administration faced considerable resistance during the latest attempt to help Americans get affordable health coverage. The debate can be traced back to efforts between 1915 and 1920, when progressive reformers were proposing plans to cover workers with compulsory health insurance.

During the nineteenth and early twentieth centuries, Americans could turn to fraternal organizations, trade unions, workplace-based mutual benefit associations, commercial insurers, and discretionary charity to insure against income losses as a result of sickness. The largest source of sickness protection was through friendly societies-voluntary organizations such as fraternal orders and trade unions that provided stipulated amounts of "relief" for members who became sick and unable to work. The largest fraternal society, the Independent Order of Odd Fellows (IOOF), provided a weekly sickness benefit of $\$ 3$ to members who paid annual membership dues of $\$ 6$.

This form of protection to workers was deemed inadequate by many observers of the time. The American Association of Labor Legislation's (AALL) 1916 proposed compulsory health insurance for workers called for cash sickness benefits at a rate of $2 / 3$ of weekly wages [1]. While the proposal set the cost at $4 \%$ of wages, the distribution of costs between worker, employer, and state was not clearly defined. Despite active promotion, the AALL proposal died in many US states. Was it because the proposal was antiAmerican in spirit, or was it because most Americans were not in need of it? Emery [2] suggested that Americans had the capacity to self-insure through savings, and in the early stages of their working lives, voluntary sickness insurance arrangements provided satisfactory protection. Americans did not need lifetime compulsory sickness insurance.

This paper contributes to the existing literature on friendly societies, government health insurance, and on the propensity of Americans to self-insure by presenting a lifecycle model with sickness risk to further explore why Americans did not want compulsory health insurance. The model is used to quantify the conditions under which workers would demand the sickness benefit provided by friendly societies and is used to compare the attractiveness of the voluntary sickness benefit, the compulsory health insurance proposal, and the self-insurance option for American workers after WWI. Results from lifecycle simulations support the conclusion that Americans did not need the compulsory health insurance program as proposed by the AALL: the program did not appear to be welfare-enhancing. Voluntary sickness insurance met the needs of young workers who did not have enough savings to self-insure. Older workers had the capacity 
to self-insure through accumulated savings. Model results also suggest that the compulsory health insurance premium would have to fall to or below $2.1 \%$ to attract both young and old workers over voluntary sickness insurance and selfinsurance options.

\section{Voluntary Self-Help Arrangements for Sickness Risk}

During the nineteenth and early twentieth centuries, American workers faced considerable income risk, including that due to industrial accidents, sickness, and unemployment [35]. Friendly societies played the largest role amongst the varied institutions that provided workers with insurance against lost wages due to illness. From the late eighteenth and early nineteenth centuries, friendly societies were often local lodges with no affiliations to other lodges. Over time, larger orders that consisted of local lodges affiliated under jurisdictional grand lodges and national or international supreme bodies displaced the purely local lodge [6-8]. The Ancient Order of Foresters was one of England's larger affiliated orders, and it had subordinate courts and jurisdictions in North America. The Independent Order of Odd Fellows (IOOF), the largest friendly society in North America, opened its first subordinate lodge in Baltimore in 1819 under the jurisdiction of the British IOOF Manchester Unity (IOOFMU). In the 1840s, the North American Odd Fellows seceded from the IOOFMU and founded the IOOF Sovereign Grand Lodge that had jurisdiction over state and provincelevel Grand Lodge jurisdictions in North America.

Friendly society sick benefits exemplified classic features of working-class insurance: a low cost and a small benefit of fixed amount equal to part of the wages of a worker with average wages. By contrast, commercial policies for middleclass clients offered insurance in variable amounts up to fullincome replacement, at a cost beyond the reach of most workers. The affiliated orders established constitutions which standardized rules and arrangements for sick benefit provision. For most of the friendly societies, local lodges or courts paid the sick claims of their members. Subject to requirements of higher bodies, the local lodge set the amounts of weekly benefits, joining fees, and membership dues. The affiliation of lodges across locations also resulted in members having portable sickness insurance. If a member moved from one location to another, he could transfer his membership from one lodge to another within the organization. To claim benefits in the IOOF, a member had to provide his lodge with notice of sickness or disability within a week of its commencement. On receiving notice of a brother's illness, a member of the visiting committee was to visit the brother within twenty-four hours to render him aid and confirm his sickness. Subsequently, the lodge visitors reported weekly on the brother's condition until he recovered.

On balance, friendly societies provided an efficient delivery of working-class sickness insurance that commercial insurers could not match. The local lodge or court system of the affiliated friendly societies like the IOOF and the Ancient Order of Foresters had important strengths for the sickness insurance market. First, it had low overhead costs. Lodge members, not paid agents, recruited clients. Nominally paid or unpaid lodge officers did the administrative work. Second, the intrusive methods of monitoring within the lodge system helped friendly societies to respond effectively to two classic problems in sickness insurance: adverse selection and moral hazard. Organizations like the IOOF scaled initiation fees, or membership dues, by the age of an initiate to discourage applications from older males, who had above-average sickness risk, to mitigate the adverse selection problem. Lodgeapproved physicians examined the physical condition and health history of an applicant, and a lodge committee investigated his moral character. The ministrations of the lodge visiting committee and restrictions on behaviour while claiming benefits helped to ward off false claims to mitigate the moral hazard problem. In addition, fraternal ideology emphasized a member's moral responsibility for not making a false claim and for reporting on brothers who were falsely claiming benefits. "The assurance of a stipulated sum during sickness," the president of the Prudential Insurance Company conceded in 1909, "can only safely be transacted... by fraternal organizations having a perfect knowledge of and complete supervision over the individual members" [9].

Millis [10] reported that 30 percent of Illinois wage earners had market insurance for disability risk in 1919 where fraternal organizations were the principal source of market insurance. Beito [11] argued that a conservative estimate of participation in fraternal self-help organizations in the United States would have one of three adult males as a member in 1920.

2.1. IOOF Sickness Insurance. Before 1927, the IOOF was the largest sickness insurer in the United States [12]. As a member of the IOOF, an individual who became ill was eligible for a cash benefit of between $\$ 3$ and $\$ 5$ per week of disability. These benefits were payable beginning from the eighth day of disability for up to a whole year. After a full year of sickness, the benefit was reduced to $\$ 1$ per week. At the lodge's discretion, physicians could be contracted to provide medical attendance and medicines, but attentive benefits (nursing and care-giving) provided by lodge brothers were mandatory. While there were no maternity benefits, the IOOF did provide for widows and orphans, and some lodges offered funeral benefits of $\$ 30$ to $\$ 100$. Lodges could also choose to increase the amount of the cash payment to members in need, or to pay for medical assistance. The cost of this sickness insurance coverage was $\$ 6$ to $\$ 10$ per year, with nominal one-time joining fees. Additional sickness coverage could be increased by joining an IOOF auxiliary branch at the same cost, or by joining other organizations [12]. For a $\$ 600$ earner, the cost of IOOF sickness insurance was 1 percent to 1.5 percent of annual earnings for a weekly sickness benefit of $\$ 3$ to $\$ 5$.

\section{Compulsory Health Insurance}

Most scholarly examinations of voluntary methods of selfhelp in England and North America conclude that voluntary income protection was "woefully inadequate" [4] if not 
a "dismal failure for meeting the economic and medical needs of a populace" [13]. Rodgers [14] described the voluntary mutual assistance arrangements available on both sides of the Atlantic as "both a fixture of everyday life and inadequate to it, far-flung and full of holes." Critics of voluntary self-help argue that it was a deficient arrangement, and its obvious shortcomings were the impetus for the establishment of government social insurance $[6,7,15,16]$. England introduced compulsory state health insurance in 1911. Soon after, progressive reformers in seventeen US states crusaded for compulsory state health insurance $[11,13]$.

3.1. The AALL Plan. The American Association of Labor Legislation proposed a draft of an act for compulsory health insurance (CHI) in 1916. The program was designed to cover all manual workers, clerks, and foremen who earned less than $\$ 1,200$ per year. Others, including the self-employed, with earnings of less than $\$ 1,200$ per year could voluntarily join the program. The draft act proposed cash benefits equal to $2 / 3$ of weekly wages. These benefits would be payable starting on the fourth day of illness and up to a maximum of twenty-six weeks in any twelve-month period. The plan would provide medical, surgical, and nursing services and supplies to the worker and dependants, as well as limited maternity and funeral benefits [1].

The cost of the insurance was not clearly defined. Given the German experience with CHI, the AALL suggested that a premium of four percent of wages would be required [17]. It was the AALL's belief that illness would be prevented if employers and government shared the cost of insurance [2]. Assuming that employers would pay up to forty percent of the insurance costs, and government would pay up to twenty percent, then the cost to workers could be as low as 1.6 percent of wages $[9,18,19]$. The recommendation of costsharing was to make the plan more appealing to wage earners since they would gain more generous insurance coverage at a lower cost. Of course, this all hinged on whether or not the cost to employers would ultimately be passed down onto workers with reduced or stagnant wages.

3.2. Comparing the AALL and IOOF Plans. The AALL plan attempted to fill the wide gap between a worker's earnings and the voluntary insurance sickness benefit. The AALL CHI plan was much more generous than the existing voluntary insurance arrangements. It was also more expensive. Assuming a CHI premium of four percent of earnings, a wage earner with annual income of $\$ 600$ would have been compelled to pay $\$ 24$ per year for health insurance coverage. On the assumption that state taxes and wage rates did not change in response, and that employers and the state paid sixty percent of the premium cost, then wage earners would have secured the benefits of $\mathrm{CHI}$ for as little as $\$ 10$. If the cash benefit paid while sick would have been $2 / 3$ of the weekly wage as proposed, then the worker with $\$ 600$ in annual earnings would be eligible to receive a sickness benefit of $\$ 7.70$ per week. In comparison, for a $\$ 600$ earner, the cost of IOOF sickness insurance at $\$ 6$ to $\$ 10$ per year was 1 to 1.5 percent of annual earnings to secure a weekly sickness benefit of $\$ 3$ to $\$ 5$.
Emery [2] provided a comparison of the costs and benefits of the AALL and IOOF programs for individuals of different ages and illness risks and different income levels. The average sickness duration for workers over 20 was 0.88 weeks. For a $\$ 600$ annual wage earner, the AALL arrangement would provide on average $\$ 6.81$ in cash benefits, whereas with the IOOF cash benefits of $\$ 3$ to $\$ 5$ per week of sickness, they could expect to receive $\$ 2.64$ to $\$ 4.40$. Comparing the expected value of cash benefits to premium contributions, a CHI premium of $2.6 \%$ would match the cost of IOOF sickness insurance. This is much lower than the actuarially sound premium of $4 \%$ suggested for CHI: the IOOF plan benefited by selling memberships to young workers in the early years of lodge existence and could then draw on investment income to help pay out benefits in the future. This suggests that a worker premium of four percent for CHI would be too high in terms of dollars of expected benefit to dollars of expected contribution relative to what was available from voluntary insurance providers. The major advantage of the $\mathrm{CHI}$ contract was that as income increased, so did the cash sickness benefit; the benefit from the voluntary IOOF contract was fixed regardless of income. However, the voluntary IOOF contract better-insured the long-term chronic illness of older workers since members were eligible for sickness benefits for up to a full year, rather than a half-year under CHI.

Horrell and Oxley [4], while pointing out its inadequacies, suggested that the voluntary sickness benefit may not have been intended as a primary source of coverage. The benefit could be viewed as a complement for risk mitigation strategies like increasing the labour supply by family members, reducing household expenditures, or spending from accumulated savings. They pointed out that "even small returns may have been vital to well-being" even though the benefits "were not adequate to match the loss of earnings occasioned by misfortune.” Beito [11] also wrote that fraternal ritual emphasized the benefits of thrift and frugality in aiding a member in achieving a state of economic selfreliance. From this latter perspective, we can see that it is possible that less than complete loss replacement was not a shortcoming of formal self-help if its purpose was to encourage a household to develop its own capacities for risk coverage. In turn, if this was the role of friendly society benefits, we should not be surprised to find that friendly society membership was not a life-long purchase for many members, as those who joined initially to acquire insurance coverage may have had a diminishing demand for the benefits over the lifecycle. G. Emery and J. C. H. Emery [12] found that these voluntary insurance programs provided a "young man's benefit," and the fact that many memberships were abandoned within a few years was a sign that the insurance provided temporary assistance only as needed: men who joined primarily for the insurance benefit typically held memberships for a duration of between three and seven years. ${ }^{1}$

The AALL CHI proposal, with its higher cost, was intended to benefit low-wage earners who chose not to purchase the lower-cost fraternal sickness insurance. At the time, some opponents of the CHI movement in the United States painted the proposal as a compulsory savings scheme 
designed to force workers into a high-cost insurance program [14]. Did the AALL insurance plan have economic merit and value for Americans? In the next section, we build on the precautionary savings literature and present a lifecycle model with sickness risk.

\section{Precautionary Savings}

Friendly society sickness insurance was a form of savings [20, 21]. In particular, the friendly benefits were contingent claim savings where an individual purchased a security (insurance contract) that paid a return only if a defined state (inability to work) occurred. Thus, in return for the payment of membership dues, the lodge paid a benefit to a member who was sick and unable to work. An alternative to purchasing this contingent claim contract was for an individual to set aside a portion of current income that could be drawn upon in the event he was sick and unable to work. Both options are examples of precautionary saving.

There are important differences between the forms of saving. First, as a contingent claim that expires at the end of a specified period, the friendly sick benefit provided an individual with a lower-priced security since the insured risk of the individual was pooled with those of other members. Second, because the contingent claim expires after a specified period of time, the income used to purchase the security is not retained. In contrast, direct saving (holding a part of income as a reserve) carries forward in the event the individual does not experience an income loss due to sickness. Finally, the friendly society sick benefits were not an asset that was usable as collateral to borrow against future labour income to increase current consumption (life insurance contracts provide an analogy for this distinction: purchasing the friendly sick benefit is akin to purchasing term life insurance, while the accumulation of wealth through personal savings is akin to purchasing ordinary, or whole-life, life insurance).

Recognizing that the friendly society sick benefit was a form of precautionary saving, we can draw on a large literature in economics [22-30]. When future income is variable and uncertain, households with low levels of wealth and an inability to borrow against future labour earnings will engage in precautionary saving. Thus, cash on hand and/or contingent claims contracts are assets that act as a buffer stock of consumption that a household can draw upon in the event that current income is low due to illness or other interruptions to work. Gourinchas and Parker [30] showed that precautionary savings are especially important at young ages where households hold little wealth and depend on labour income for consumption. This assertion is of particular relevance to this study and the finding that voluntary sickness insurance was a young man's benefit.

Americans during the late nineteenth and early twentieth centuries faced several different types of income shocks, including unemployment and workplace accidents. James et al. [5] examined US survey data from 1879 to 1909 and found that working-class American families in the late eighteenth and early nineteenth centuries had high marginal propensities to save out of transitory income, indicating a very strong precautionary savings motive, to insure against income uncertainty, and perhaps up to three-quarters of private savings were for precautionary reasons. Kantor and Fishback [3] estimated that the introduction of worker's compensation in the 1910s alleviated part of the precautionary savings motive of Americans and reduced private savings by approximately twenty-five percent.

4.1. Saving Over the Lifecycle with Sickness Risk. We use a lifecycle model with sickness risk to help determine why the compulsory health insurance movement did not succeed in the US after WWI. In particular, we model the precautionary savings motive of workers and the attraction of voluntary and compulsory sickness insurance programs, as well as the selfinsurance option.

Consider an environment in which individuals face a probability of sickness over their lifecycle that is age-dependent. As such, agents are faced with the precautionary saving problem: how much to privately save to self-insure against illness, and whether or not to purchase sickness insurance. Agents are rational and forward-looking, who wish to maximize expected lifetime utility over a standard composite good. The composite good may be used for consumption, $c$, or used as a capital asset, $a$, earning a oneperiod rate of return denoted by $r$. The individual has timeseparable preferences and a discount factor denoted by $\beta$. The individual, in period 0 , who will live until period $I$, wishes to maximize expected lifetime utility given by

$$
\max E_{0}\left(\sum_{i=1}^{I} \beta^{i} U\left(c_{i}\right)\right), \quad \text { where } U(c)=\frac{c^{1-\sigma}}{1-\sigma}-\frac{K^{1-\sigma}}{1-\sigma} .
$$

In this utility function, $K$ is a scale parameter used to center the utility function, so that $U(K)$ is equal to zero. $K$ is similar to a subsistence level of consumption, so that consumption levels below $K$ generate negative utility values, and consumption levels above $K$ generate positive utility values.

The individual faces an earnings profile over the lifecycle that is known in advance, and earnings in period $i$ are denoted by $e_{i}$. The individual is also assumed to know the probability of being sick and unable to work over the lifecycle. The probability of being sick in period $i$ is denoted by $p_{i}$. The individual may participate in a sickness insurance program. Dues, denoted by $d_{i}$, are paid to participate in the program in period $i$, and if the individual becomes ill and unable to work, the insurance contract pays benefits equal to $b_{i}$. The individual is constrained to consume nonnegative levels of consumption and is also constrained to always have non-negative levels of wealth (the agent cannot borrow against expected future earnings but may mortgage existing wealth). If the agent works in period $i$, then his working status, denoted by $l$, is 1 . If the agent is sick in period $i$, then his working status, $l$, is 0 .

In period $i$, the individual chooses consumption $c_{i}$ and private asset holdings, $a_{i}^{\prime}=a_{i+1}$, that are carried into the next period, with the following constraints:

$$
\begin{gathered}
c_{i}+a_{i}^{\prime} \leq W_{i}=a_{i}+\left(r a_{i}+l_{i} e_{i}-d_{i}+\left(1-l_{i}\right) b_{i}\right), \\
c_{i} \geq 0, \quad a_{i}^{\prime} \geq 0 \quad \forall i,
\end{gathered}
$$


$l_{i}=0$ with probability $p_{i}$ (sick), and $l_{i}=1$ with probability $1-p_{i}$ (working). The values for $d_{i}$ and $b_{i}$ are defined by the insurance program.

In order to simulate the lifecycle model, a set of parameters need to be calibrated to the early twentieth century context. Lee [31] indicated that, at the beginning of the twentieth century, the average 20-year-old male could expect to work for 40 years and retire from work for 3 years before dying. To simplify the exercises, the assumption is made that individuals join the labour force immediately following their 20th birthday. They will be in the labour force for 40 years, retire on their 60th birthday, and die on their 63rd birthday. In this case, there are no accidental bequests from premature death, and there is a retirement savings motive to provide for consumption in the three years of retirement. For the purpose of these exercises, one period was set equal to two months, with six periods each year. To simplify the calibrated exercises, the probability of being sick in any period is independent of being sick in any other period. The annual age-dependent sickness rates for 1896-1898 were used, as presented in Emery [2], and were divided by 6 for conversion to bi-monthly rates. ${ }^{2}$

A voluntary sickness insurance association, the IOOF, offered a contract that specified annual dues of $\$ 6$, with a payout of $\$ 3$ per week if ill. Agents were not required to renew the contract in subsequent years. The average duration of sickness for claimants was seven weeks [12]. For the IOOF voluntary sickness insurance program, the payment of dues, $d$, was set to $\$ 1$ for every period of participation in the program, starting with the first period ( $\$ 6$ annual dues paid over six bi-monthly periods), and the level of benefits was set to $\$ 24$ in a period when the individual was sick and did not receive wages. These amounts are fixed in nominal terms. Since the model requires items to be stated in real terms, the value of these items is deflated at a rate of $0.33 \%$ per period, to obtain real values, which fall over time. The compulsory health insurance program is one in which members receive sickness benefits equal to $2 / 3$ of their wages, and the premium paid by workers is $4 \%$ of wages. The premium rate will be varied to investigate the attractiveness of the $\mathrm{CHI}$ program at different premium rates.

The value of $K$ is set to 24 , which is also equal to the sickness benefit per period provided by the voluntary insurance contract at the beginning of the study period. This value is fixed in real terms. Two earnings profiles were generated using the 1917-1919 US Bureau of Labor Statistics Cost of Living Survey. The "high" earnings profile uses the estimated wage equation from this survey to construct age-dependent earnings and is adjusted to provide a profile that is close to the $\$ 1,200$ maximum earnings limit for the AALL proposal. ${ }^{3}$ Earnings from this profile start at $\$ 1,047$ for a 20 -year-old worker, rise to the peak of $\$ 1,200$ for a 35 -year-old worker, and decline to $\$ 866$ for a 59 -year-old worker. The "low" earnings profile is set to straddle the $\$ 600$ annual income figure used in many calculations in Emery [2]. Wages in this profile start at $\$ 541$, rise to $\$ 621$ at age 35 , and fall to $\$ 448$ by age 59. These two earnings profiles were converted to a timeseries profile using a growth rate of $0.33 \%$ per period. The real rate of return is also set at $0.33 \%$ per 2 -month period. In these exercises, the annual growth rate of wages, the annual rate of inflation, and the real interest rate are all held at $2 \% .^{5}$

For simulations with no mortality risk, the annual discount parameter, $\beta$, varies and has been set between 1 and 0.96 (as examples, see [34-36]). While some empirical estimates for the risk aversion parameter, $\sigma$, have exceeded 6, simulation values for $\sigma$ tend to stay in the range of 1 to 5 , deemed a plausible range by economists $[28,34-38]$. The discount rate and level of risk aversion were varied in an attempt to calibrate the model, so that agents upon entry into the labour market prefer voluntary sickness insurance coverage that lasts between three and seven years. In the simulations, the bi-monthly value of $\beta$ varied from 0.998 (an annual rate of time preference equal to $1 \%$ ) to 0.984 (an annual rate of time preference equal to $10 \%$ ). The value of $\sigma$, the constant relative risk aversion parameter, was set to range from 1.2 to 4 .

The simulation exercises generated expected lifetime utility values for agents under the following circumstances:

(i) the individual never participates in a sickness insurance program;

(ii) the individual participates in the voluntary insurance program beginning at age 20 , but withdraws from the program after a predetermined length of time (1-, 3-, 5-, 7-, 10-, and 40-year associations were examined);

(iii) the individual participates in a compulsory health insurance program from the age of 20 to the age of 59 (40 years).

The computational procedure is described in the appendix. Simulations were performed using Ox 2.20 [39].

The objective of the first set of simulation exercises is to examine the attractiveness of the voluntary sickness insurance contract offered by the IOOF and of the compulsory health insurance contract proposed by the AALL. These simulations will also help to estimate a worker contribution rate that would make the AALL proposal for sickness insurance a preferred life option for new workers. The objective of the second set of simulations is to determine the threshold wealth levels at which agents at various ages would prefer to self-insure, in order to get a sense of the attractiveness of the IOOF and AALL insurance options.

4.2. Simulation Results. While simulating the model with different rates of time preference, we found that the optimal voluntary sickness insurance contract duration increases, and the threshold wealth level increases, with increasing rates of time preference (more "impatience" and a lower value of $\beta$ ). Those with higher rates of time preference (larger discounting of future consumption) wish to consume more today and are slower to build up a buffer of savings on their own for precautionary purposes. The longer contract terms provide this buffer against bad states (illness) much better and under more favourable terms than the agent's preference and ability to self-insure when relatively impatient. Simulations also indicated that increasing rates of risk aversion lead to stronger preference for longer voluntary sickness insurance contracts and lead to higher threshold wealth levels. 
TABLE 1: Comparison of results, low earnings profile $(\sigma=2, \beta=0.997)$.

\begin{tabular}{|c|c|c|c|c|c|c|c|c|c|}
\hline \multirow[b]{2}{*}{$\begin{array}{l}\text { Initial } \\
\text { wealth } \\
(\$)\end{array}$} & \multicolumn{9}{|c|}{ Expected lifetime utility for } \\
\hline & $\begin{array}{l}\text { No insurance } \\
\text { over lifetime }\end{array}$ & $\begin{array}{l}\text { IOOF } \\
\text { insurance for } \\
\text { first year } \\
\text { only }\end{array}$ & $\begin{array}{l}\text { IOOF } \\
\text { insurance for } \\
\text { first } 3 \text { years } \\
\text { only }\end{array}$ & $\begin{array}{l}\text { IOOF } \\
\text { insurance for } \\
\text { first } 5 \text { years } \\
\text { only }\end{array}$ & $\begin{array}{l}\text { IOOF } \\
\text { insurance for } \\
\text { first } 7 \text { years } \\
\text { only }\end{array}$ & $\begin{array}{l}\text { IOOF } \\
\text { insurance for } \\
40 \text { years }\end{array}$ & $\begin{array}{l}\text { AALL } \\
\text { insurance } \\
(4.0 \% \\
\text { premium) }\end{array}$ & $\begin{array}{l}\text { AALL } \\
\text { insurance } \\
(2.6 \% \\
\text { premium })\end{array}$ & $\begin{array}{l}\text { AALL } \\
\text { insurance } \\
(2.1 \% \\
\text { premium })\end{array}$ \\
\hline 0 & $-\infty$ & 6.0484 & 6.0487 & 6.0488 & 6.0488 & 6.0481 & 6.0206 & 6.0420 & 6.0495 \\
\hline 2 & 3.9284 & 6.0488 & 6.0491 & 6.0491 & 6.0491 & 6.0484 & 6.0209 & 6.0423 & 6.0497 \\
\hline 4 & 6.0129 & 6.0492 & 6.0494 & 6.0495 & 6.0495 & 6.0488 & 6.0212 & 6.0425 & 6.0500 \\
\hline 6 & 6.0420 & 6.0495 & 6.0498 & 6.0498 & 6.0498 & 6.0491 & 6.0215 & 6.0428 & 6.0503 \\
\hline 8 & 6.0458 & 6.0499 & 6.0501 & 6.0501 & 6.0501 & 6.0495 & 6.0218 & 6.0431 & 6.0505 \\
\hline 10 & 6.0473 & 6.0502 & 6.0504 & 6.0505 & 6.0505 & 6.0498 & 6.0220 & 6.0433 & 6.0508 \\
\hline 22 & 6.0513 & 6.0521 & 6.0522 & 6.0523 & 6.0523 & 6.0516 & 6.0236 & 6.0449 & 6.0523 \\
\hline 44 & 6.0552 & 6.0553 & 6.0553 & 6.0553 & 6.0553 & 6.0546 & 6.0264 & 6.0475 & 6.0550 \\
\hline 46 & 6.0555 & 6.0555 & 6.0555 & 6.0555 & 6.0555 & 6.0548 & 6.0266 & 6.0478 & 6.0552 \\
\hline 48 & 6.0558 & 6.0558 & 6.0558 & 6.0558 & 6.0558 & 6.0551 & 6.0269 & 6.0480 & 6.0554 \\
\hline 50 & 6.0561 & 6.0561 & 6.0560 & 6.0560 & 6.0560 & 6.0554 & 6.0271 & 6.0483 & 6.0557 \\
\hline 120 & 6.0651 & 6.0648 & 6.0643 & 6.0642 & 6.0642 & 6.0635 & 6.0351 & 6.0560 & 6.0634 \\
\hline
\end{tabular}

Note: values in boldface show the highest expected lifetime utility for a given value of initial wealth across the given insurance options.

With higher rates of risk aversion, agents desire the security of the sickness insurance contract and desire a larger buffer of wealth, to protect against bad states. Of the combinations of risk aversion and time preference examined, the parameters that seem best able to replicate the desire for short-term insurance were $\sigma=2$ and $\beta=0.997$, which corresponds to an annual rate of time preference of $1.8 \%{ }^{6}$

Tables 1 and 2 present the results from simulating the utility maximization problem described in (1) and (2), for the new worker, focusing on the financial conditions under which a new labourer would choose to buy the voluntary sickness contract offered by the IOOF. Results are also presented for the compulsory insurance contract at different contribution rates. Results from 1, 3, 5, 7, and 40-year IOOF associations are presented. The results of the simulations under an AALL plan with contribution rates set at $4.0 \%$ of earnings are examined since that was the contribution rate that was proposed as being actuarially sound. Results are also presented for $\mathrm{CHI}$ programs where workers pay contribution rates of $2.6 \%$, to compare with the equivalent cost to benefit ratio of the IOOF plan [2], and of $2.1 \%$ of wages.

Table 1 presents the simulation results for the low-earnings profile. The results suggest that agents will prefer fiveto seven-year associations with the IOOF over no insurance for initial wealth levels less than $\$ 46$, and self-insurance at initial wealth levels above $\$ 50$. Note that agents will not prefer the AALL plan with contributions set at $4.0 \%$ or $2.6 \%$ of wages over short-term IOOF memberships, at any initial wealth level. Agents, however, would prefer the compulsory health insurance program over the IOOF plan and over selfinsurance if the contribution rate was $2.1 \%$ of wages and if initial wealth was less than $\$ 22$.

Table 2 presents the results for agents under the highearnings profile. Given the calibration parameters, agents would prefer seven-year associations with the IOOF for sickness insurance, if new workers held less than $\$ 132$ in initial wealth, and would prefer to self-insure if they held more. AALL compulsory health insurance would be more attractive to new workers than the voluntary sickness insurance plan with wealth less than $\$ 22$, only if the contribution rate was $2.1 \%$ of wages or less. Higher contribution rates would be unattractive relative to the IOOF contract.

These results show that larger incomes are associated with higher threshold levels for self-insurance; those with larger incomes are more willing to purchase insurance because they are insuring against a much larger income drop than those with lower incomes. In addition, the results suggest that a high-cost and high-benefit AALL plan which has the same cost-benefit ratio as the IOOF plan is not preferred over the low-cost and low-benefit option; the AALL proposal with the wage premium set at $2.6 \%$ of wages is not attractive when compared to the IOOF contract. This is because the marginal expected utility of increasing insurance is declining, just as the marginal utility of increasing consumption is declining.

The second set of simulations investigates the decision being faced by workers of different ages. In particular, we wish to examine how much wealth individuals, of increasing age, would need to hold in order to be attracted to the AALL plan or to the IOOF plan. In these simulations, the expected utility of agents is examined at the ages of 25 (5 years of labour force experience), 30 (10 years), 35 (15 years), 40 (20 years), 45 (25 years), 50 (30 years), and 55 (35 years), when the decision to buy insurance, to self-insure, or to favour the AALL proposal, is being made.

Table 3 summarizes the results of the second set of simulations under the low-wage profile. The table shows an estimated average annual savings figure given the wage profile used in the simulations and the median savings rates presented in Emery [2]. The table then presents the threshold wealth levels for which agents will choose to self-insure versus the respective insurance program. Accompanying 
TABLE 2: Comparison of results, high earnings profile $(\sigma=2, \beta=0.997)$.

\begin{tabular}{|c|c|c|c|c|c|c|c|c|c|}
\hline \multirow[b]{2}{*}{$\begin{array}{l}\text { Initial } \\
\text { wealth } \\
(\$)\end{array}$} & \multicolumn{9}{|c|}{ Expected lifetime utility for } \\
\hline & $\begin{array}{l}\text { No insurance } \\
\text { over lifetime }\end{array}$ & $\begin{array}{l}\text { IOOF } \\
\text { insurance for } \\
\text { first year } \\
\text { only }\end{array}$ & $\begin{array}{l}\text { IOOF } \\
\text { insurance for } \\
\text { first } 3 \text { years } \\
\text { only }\end{array}$ & $\begin{array}{l}\text { IOOF } \\
\text { insurance for } \\
\text { first } 5 \text { years } \\
\text { only }\end{array}$ & $\begin{array}{l}\text { IOOF } \\
\text { insurance } \\
\text { for first } 7 \\
\text { years only }\end{array}$ & $\begin{array}{l}\text { IOOF } \\
\text { insurance } \\
\text { for } 40 \text { years }\end{array}$ & $\begin{array}{l}\text { AALL } \\
\text { insurance } \\
(4.0 \% \\
\text { premium) }\end{array}$ & $\begin{array}{l}\text { AALL } \\
\text { insurance } \\
(2.6 \% \\
\text { premium })\end{array}$ & $\begin{array}{l}\text { AALL } \\
\text { insurance } \\
(2.1 \% \\
\text { premium })\end{array}$ \\
\hline 0 & $-\infty$ & 6.7455 & 6.7457 & 6.7457 & 6.7457 & 6.7456 & 6.7314 & 6.7424 & 6.7463 \\
\hline 2 & 4.6258 & 6.7457 & 6.7458 & 6.7458 & 6.7459 & 6.7457 & 6.7315 & 6.7425 & 6.7463 \\
\hline 4 & 6.7100 & 6.7458 & 6.7459 & 6.7459 & 6.7460 & 6.7458 & 6.7315 & 6.7426 & 6.7464 \\
\hline 6 & 6.7388 & 6.7459 & 6.7461 & 6.7461 & 6.7461 & 6.7460 & 6.7316 & 6.7426 & 6.7465 \\
\hline 8 & 6.7423 & 6.7461 & 6.7462 & 6.7462 & 6.7463 & 6.7461 & 6.7317 & 6.7427 & 6.7466 \\
\hline 10 & 6.7435 & 6.7462 & 6.7463 & 6.7463 & 6.7464 & 6.7462 & 6.7318 & 6.7428 & 6.7466 \\
\hline 22 & 6.7459 & 6.7468 & 6.7469 & 6.7469 & 6.7470 & 6.7468 & 6.7322 & 6.7432 & 6.7470 \\
\hline 130 & 6.7510 & 6.7510 & 6.7510 & 6.7510 & 6.7511 & 6.7509 & 6.7357 & 6.7467 & 6.7505 \\
\hline 132 & 6.7511 & 6.7511 & 6.7511 & 6.7511 & 6.7511 & 6.7510 & 6.7358 & 6.7467 & 6.7505 \\
\hline 240 & 6.7547 & 6.7546 & 6.7545 & 6.7545 & 6.7545 & 6.7543 & 6.7390 & 6.7499 & 6.7536 \\
\hline
\end{tabular}

Note: values in boldface show the highest expected lifetime utility for a given value of initial wealth across the given insurance options.

TABLe 3: Minimum wealth levels that would induce preference for self-insurance by age ( $\sigma=2, \beta=0.997$, low earnings).

\begin{tabular}{|c|c|c|c|c|c|c|c|c|}
\hline Age & $\begin{array}{c}\text { Years at } \\
\text { work }\end{array}$ & $\begin{array}{l}\text { Median } \\
\text { savings } \\
\text { rates }^{*}\end{array}$ & $\begin{array}{l}\text { Estimated } \\
\text { annual } \\
\text { savings }{ }^{* *}\end{array}$ & $\begin{array}{c}\text { Versus IOOF } \\
\text { plan for one } \\
\text { more year }\end{array}$ & $\begin{array}{l}\text { Versus IOOF plan } \\
\text { to age } 60 \text { (multiple } \\
\text { of annual savings) }\end{array}$ & $\begin{array}{l}\text { Versus AALL plan } \\
\text { with } 4.0 \% \text { wage } \\
\text { premium to age } 60\end{array}$ & $\begin{array}{l}\text { Versus AALL plan } \\
\text { with } 2.6 \% \text { wage } \\
\text { premium to age } 60\end{array}$ & $\begin{array}{l}\text { Versus AALL plan } \\
\text { with } 2.1 \% \text { wage } \\
\text { premium to age } 60\end{array}$ \\
\hline 25 & 5 & $3.3 \%$ & $\$ 18$ & $\$ 60(3.3)$ & $\$ 24(1.3)$ & $\$ 6$ & $\$ 8$ & $\$ 40(2.2)$ \\
\hline 30 & 10 & $3.8 \%$ & $\$ 23$ & $\$ 62(2.7)$ & $\$ 22(1.0)$ & $\$ 6$ & $\$ 8$ & $\$ 38(1.7)$ \\
\hline 35 & 15 & $4.1 \%$ & $\$ 25$ & $\$ 66(2.6)$ & $\$ 22(0.9)$ & $\$ 6$ & $\$ 8$ & $\$ 44(1.8)$ \\
\hline 40 & 20 & $4.0 \%$ & $\$ 25$ & $\$ 68(2.7)$ & $\$ 24(1.0)$ & $\$ 6$ & $\$ 12$ & $\$ 130(5.2)$ \\
\hline 45 & 25 & $4.4 \%$ & $\$ 27$ & $\$ 64(2.4)$ & $\$ 28(1.0)$ & $\$ 6$ & $\$ 18$ & $* * *$ \\
\hline 50 & 30 & $5.2 \%$ & $\$ 30$ & $\$ 62(2.1)$ & $\$ 40(1.3)$ & $\$ 8$ & $\$ 52(1.7)$ & $* * *$ \\
\hline 55 & 35 & $6.8 \%$ & $\$ 36$ & $\$ 60(1.7)$ & $\$ 1,754(49)$ & $\$ 10$ & $* * *$ & $* * *$ \\
\hline
\end{tabular}

* Median savings rates for 5-year age groups as reported in Emery [2], using the 1917-1919 US data, including zero surpluses with mortgage expenses. The median savings rate for those aged 20-24 (25-29) was used for the individual with 5 (10) years of work experience, and so forth.

**Average of previous 5 years labour income times the median savings rate for 5 -year age groups.

$* * *$ Wealth levels considered are in the range from 0 to $\$ 6,000$. Self-insurance was not preferred to the given insurance plan at any wealth level in this range.

the threshold wealth level is a ratio of this wealth level to the annual savings figure. This ratio provides a rough guide to the ability of workers to meet the threshold wealth level even though we acknowledge that actual savings rates may vary widely across individuals by income, age, and employment history within an age group. The results suggest that workers with five years of work experience or more should have accumulated enough wealth to abandon an ongoing IOOF membership, and not be in need of their sickness insurance coverage. Note that for all but senior workers, the one-year IOOF contract is attractive to those who have not been able to accumulate much wealth. Those with more than 35 years of work experience would prefer the sickness insurance provided by IOOF membership over selfinsurance for the rest of their working lives (but they would probably not be accepted given the lodges' desire to prevent old and risky workers from membership). The AALL plan with contribution rates set at $2.1 \%$ of wages is attractive only to workers older than 40. An AALL plan with contribution rates set at $4 \%$ would be attractive to no workers, and an AALL plan with the contribution rate set at $2.6 \%$ would only be attractive to those with more than 30 years of work experience.

The results presented in Table 4 suggest that only workers with very little wealth would prefer to extend their IOOF memberships one additional year and would not prefer lifetime IOOF sickness insurance. Most workers with five years of experience or more should have accumulated enough wealth to self-insure rather than desire IOOF sickness insurance. The AALL plan with the contribution rate set $2.1 \%$ of earnings would be attractive to workers with more than 20 years of work experience. The compulsory health insurance plan with the contribution rate set at $4.0 \%$ of wages is not attractive to workers of any age or earnings ability. Only old workers would be interested in the AALL plan with the contribution rate set at $2.6 \%$.

These results support the notion that the majority of Americans were capable of self-insuring for most of their working lives. Voluntary insurance was welfare-enhancing for young individuals with little accumulated wealth. Older workers did not need insurance since they had enough wealth to self-insure. ${ }^{7}$ A compulsory health insurance plan with 
TABLe 4: Minimum wealth levels that would induce preference for self-insurance by age $(\sigma=2, \beta=0.997$, high earnings).

\begin{tabular}{|c|c|c|c|c|c|c|c|c|}
\hline Age & $\begin{array}{c}\text { Years at } \\
\text { work }\end{array}$ & $\begin{array}{l}\text { Median } \\
\text { savings } \\
\text { rates* }\end{array}$ & $\begin{array}{l}\text { Estimated } \\
\text { annual } \\
\text { savings** }\end{array}$ & $\begin{array}{c}\text { Versus IOOF } \\
\text { plan for one } \\
\text { more year }\end{array}$ & $\begin{array}{l}\text { Versus IOOF plan } \\
\text { to age } 60 \text { (multiple } \\
\text { of annual savings) }\end{array}$ & $\begin{array}{l}\text { Versus AALL plan } \\
\text { with } 4.0 \% \text { wage } \\
\text { premium to age } 60\end{array}$ & $\begin{array}{l}\text { Versus AALL plan } \\
\text { with } 2.6 \% \text { wage } \\
\text { premium to age } 60\end{array}$ & $\begin{array}{c}\text { Versus AALL plan } \\
\text { with } 2.1 \% \text { wage } \\
\text { premium to age } 60\end{array}$ \\
\hline 25 & 5 & $3.3 \%$ & $\$ 36$ & $\$ 132(3.6)$ & $\$ 66(1.8)$ & $\$ 6$ & $\$ 12$ & $\$ 64(1.8)$ \\
\hline 30 & 10 & $3.8 \%$ & $\$ 44$ & $\$ 120(2.7)$ & $\$ 56(1.3)$ & $\$ 6$ & $\$ 12$ & $\$ 68(1.5)$ \\
\hline 35 & 15 & $4.1 \%$ & $\$ 49$ & $\$ 116(2.4)$ & $\$ 48(1.0)$ & $\$ 6$ & $\$ 14$ & $\$ 76(1.5)$ \\
\hline 40 & 20 & $4.0 \%$ & $\$ 48$ & $\$ 108(2.3)$ & $\$ 52(1.1)$ & $\$ 8$ & $\$ 16$ & $\$ 212(4.4)$ \\
\hline 45 & 25 & $4.4 \%$ & $\$ 51$ & $\$ 124(2.4)$ & $\$ 64(1.3)$ & $\$ 8$ & $\$ 28$ & $* * *$ \\
\hline 50 & 30 & $5.2 \%$ & $\$ 58$ & $\$ 124(2.1)$ & $\$ 90(1.6)$ & $\$ 12$ & $\$ 90(1.6)$ & $* * *$ \\
\hline 55 & 35 & $6.8 \%$ & $\$ 69$ & $\$ 120(1.7)$ & $\$ 1,224(18)$ & $\$ 14$ & $* * *$ & $* * *$ \\
\hline
\end{tabular}

${ }^{*}$ Median savings rates for 5-year age groups as reported in Emery [2], using the 1917-1919 US data, including zero surpluses with mortgage expenses. The median savings rate for those aged 20-24 (25-29) was used for the individual with 5 (10) years of work experience, and so forth.

** Average of previous 5 years labour income times the median savings rate for 5 -year age groups.

$* * *$ Wealth levels considered are in the range from 0 to $\$ 6,000$. Self-insurance was not preferred to the given insurance plan at any wealth level in this range.

a premium rate of $2.1 \%$ of wages and two-thirds income replacement would have been attractive to new workers with little wealth, and to the old who had a high probability of sickness.

Would a $2.1 \%$ wage premium have been possible? Lubove [17] noted that the AALL's proposal of a $4 \%$ wage premium was based on the German experience. The Illinois Social Insurance Commission estimated that a premium rate as high as $7.5 \%$ would be required to cover costs [9], and Murray [40] placed costs ranging from 2.5 to $5 \%$ of wages. The costs to the worker could be reduced by employer and government contributions. The AALL suggested an employee share of forty percent, with forty percent from the employer and twenty percent from the state. A forty percent share from a $4 \%$ payroll cost rate for the employee would result in an employee contribution rate of $1.6 \%$. Only if workers believed, or could be convinced, that employer and government costs would not translate into lower earnings and/or higher taxes, could workers think favourably towards the AALL proposal.

Regardless of who would cover the actuarial costs of the program, the results presented in this paper support the conclusion that $\mathrm{CHI}$ was an expensive alternative to voluntary insurance programs available to workers at the time $[2,11,12,19,40]$. High-risk workers would benefit most from the program, but those workers were older and had enough wealth to self-insure. Young workers who had yet to accumulate enough wealth to self-insure, however, would prefer the low-cost and low-benefit voluntary insurance option provided by fraternal societies like the Independent Order of Odd Fellows.

\section{Conclusion}

Progressive reformers in the United States did not convince enough American voters to support the implementation of compulsory state health insurance. From a maintained assumption that voluntary health insurance arrangements were inadequate for protecting workers and their families from the consequences of ill-health, the lack of compulsory state health insurance in the United States is interpreted as an undesirable outcome rooted in American values that interpreted socialized medicine as "un-American."

We support an alternative explanation. When viewed in the context of household savings strategies and available alternatives to collective insurance, voluntary self-help arrangements such as friendly society sick benefits provided adequate income protection for many households. As a form of precautionary saving, friendly society sick benefits were demanded by (primarily young) households with little accumulated wealth. As workers aged, they were able to save enough to wean themselves from the voluntary contract and self-insure. American workers only needed about five years of work experience, and wealth accumulation, to be self-reliant and abandon the voluntary sickness insurance provided by friendly societies like the Independent Order of Odd Fellows.

In the context of lifecycle savings for Americans after WWI, when facing sickness risk, government compulsory health insurance would not have been welfare-enhancing. The American Association of Labor Legislation's compulsory health insurance plan would only be attractive to workers if the wage premium was significantly less than the proposed rate of $4 \%$. Simulations suggest that the actual premium rate ultimately borne by workers would have to fall to approximately $2.1 \%$ of wages to become attractive over voluntary insurance schemes available at the time. The compulsory health insurance movement did not fail in the United States because it was "un-American." It failed because a large enough number of Americans were able to and preferred to self-insure and did not need it.

\section{Appendix}

\section{Computational Procedure}

The expected lifetime utility values, given the expected stream of wages that are age-dependent when working, and also given the defined sickness risk by age, are found by calculating the optimal decision rules for consumption, $c$, and private asset holdings, $a^{\prime}$, for the individual over the lifecycle, for each 2-month period, recursively from period $I$ (the last period of life, before the 63rd birthday), to the first period of 
the decision stream, period $I_{w}$. This amounts to calculating these decision rules for 258 periods in the case where the decision maker has just turned 20 years of age. The value of $a_{I}^{\prime}$ is set to zero since the agent is assumed to leave no bequest upon dying. The individual's dynamic programming problem must be solved,

$$
V(a, l)=\max _{\left(c, a^{\prime}\right)} U(c)+\beta E\left[V\left(a^{\prime}, l^{\prime}\right) \mid(a, l)\right],
$$

subject to the constraints in (2).

The decision rules are calculated by maximizing the value function on grid points defined over the state space of $a$, and by the agent's working or sickness status, $l$. Three thousand evenly spaced grid points were used for each of the variables $a$ and $a^{\prime}$ (effectively in denominations of \$2). For each value of $a$ and $l$, the single choice for $a^{\prime}$ that maximized (A.1), along with the corresponding values for consumption and $V(a, l)$, were retained as the optimal decision rules and values for each period, constructed recursively. The value for $E[V(a, l)]$ before the first period was used to identify the expected lifetime utility value for the individual given an initial value for wealth (asset holdings, $a$ ). These calculations were performed using Ox 2.20 [39].

\section{Acknowledgments}

The authors wish to thank participants at the 2011 Canadian Network for Economics History meetings held in Ottawa, Canada, and the editor and referees of this journal, for helpful comments. This work was funded in part by the SSHRC for the research program, Saving and the Welfare State.

\section{Endnotes}

1. The highest rates of membership abandonment occurred between three and seven years time after joining. Only half of men who joined IOOF lodges remained in membership for at least 10 years, and one-quarter remained for at least 30 years. This evidence provided in G. Emery and J. C. H. Emery [12] suggests that many of these long-term members desired more than just the insurance benefit that lodge membership provided. An overall participation rate of one-third, as suggested by Millis [10] and Beito [11], would be a reasonable estimate of membership prevalence when exit rates at young ages are high.

2. The annual claim rate was estimated as $\log$ (claim rate) $=-2.675+0.0019 *$ Age $+0.00035(\text { Age })^{2}$. Emery [32] claimed that these rates reflect average IOOF sickness rates for the 1902-1925 period in North America.

3. For the $1917-1919$ US dataset, $\log$ (earnings) $=6.464+$ $0.04140 *$ (age of household head) $-0.00059 *$ (age of household head $)^{2}$. For the high-earnings profile, we used $\log ($ earnings $)=6.360+0.04140 *$ (age of household head $)-0.00059 *(\text { age of household head })^{2}$.

4. For the low-earnings profile, we used $\log ($ earnings $)=$ $5.700+0.04140 *$ (age of household head $)-0.00059 *$ (age of household head) ${ }^{2}$.
5. For the $1875-1920$ period, the US inflation rate averaged $1.7 \%$, the real interest rate averaged $2.1 \%$, given data presented by Gordon [33]. The US real GDP per capita growth rate was $1.8 \%$ over 1875 to 1920 , using Gordon's data and population data from eh.net (http:// eh.net/files/databases/uspop.txt).

6. Simulations with $\sigma=2.5$ and $\beta=0.998$ or with $\sigma=1.5$ and $\beta=0.992$ produced comparable results in terms of replicating the desire for short-term insurance and threshold wealth levels at which agents would prefer to self-insure.

7. The 1917-1919 US Cost of Living survey data even indicate that average household savings rates, average household income, and the proportion of household income brought in by other family members (other than the head) were highest for households with heads aged 60 years or more. Older households were also able to self-insure across individuals within the household.

\section{References}

[1] American Association of Labor Legislation, "Health insurance-tentative draft of an act," American Labor Legislation Review, vol. 6, pp. 239-268, 1916.

[2] J. C. H. Emery, "Un-American or unnecessary? America's rejection of compulsory government health insurance in the progressive era," Explorations in Economic History, vol. 47, no. 1, pp. 68-81, 2010.

[3] S. E. Kantor and P. V. Fishback, "Precautionary saving, insurance, and the origins of workers' compensation," Journal of Political Economy, vol. 104, no. 2, pp. 419-442, 1996.

[4] S. Horrell and D. Oxley, "Work and prudence: household responses to income variation in nineteenth century Britain," European Review of Economic History, vol. 4, no. 1, pp. 27-58, 2000.

[5] J. A. James, M. G. Palumbo, and M. Thomas, "Consumption smoothing among working-class American families before social insurance," Oxford Economic Papers, vol. 59, no. 4, pp. 606-640, 2007.

[6] P. Gosden, The Friendly Societies in England 1815 to 1875, Manchester University Press, Manchester, UK, 1961.

[7] E. Hopkins, Working-Class Self-Help in Nineteenth-Century England, UCL Press, London, UK, 1995.

[8] J. Riley, Sick, Not Dead: The Health of British Working Men During the Mortality Decline, Johns Hopkins University Press, Baltimore, Md, USA, 1997.

[9] P. Starr, The Social Transformation of American Medicine, The Rise of a Sovereign Profession and the Making of a Vast Industry, Basic Books, New York, NY, USA, 1982.

[10] H. A. Millis, Sickness Insurance, Chicago University Press, Chicago, Ill, USA, 1937.

[11] D. T. Beito, From Mutual Aid to the Welfare State: Fraternal Societies and Social Services, 1890-1967, University of North Carolina Press, Chapel Hill, NC, USA, 2000.

[12] G. Emery and J. C. H. Emery, A Young Man's Benefit: The Independent Order of Odd Fellows and Sickness Insurance in the United States and Canada 1860-1929, McGill-Queen's University Press, Montreal, QC, Canada, 1999.

[13] B. Hoffman, The Wages of Sickness: The Politics of Health Insurance in Progressive America, University of North Carolina Press, Chapel Hill, NC, USA, 2001. 
[14] D. T. Rodgers, Atlantic Crossings: Social Politics in a Progressive Age, The Belknap Press of Harvard University Press, Cambridge, UK, 1998.

[15] A. Peebles, "The state and medicine," Canadian Journal of Economics and Political Studies, vol. 2, pp. 464-480, 1936.

[16] B. B. Gilbert, "The decay of nineteenth-century provident: institutions and the coming of old age pensions in Great Britain," Economic History Review, 2nd Series, vol. 17, no. 3, pp. 551563, 1965.

[17] R. Lubove, The Struggle for Social Security 1900-1935, Harvard University Press, Cambridge, UK, 1968.

[18] I. Fisher, "The need for health insurance," American Labor Legislation Review, vol. 7, pp. 9-23, 1917.

[19] D. Costa, "The political economy of state provided health insurance in the progressive era: evidence from California," National Bureau of Economic Research Working Paper 5328, 1995.

[20] S. Smiles, Thrift, Belford Brothers, Toronto, ON, Canada, 1876.

[21] P. Johnson, Saving and Spending, Clarendon Press, Oxford, UK, 1985.

[22] H. E. Leland, "Saving and uncertainty: the precautionary demand for saving," Quarterly Journal of Economics, vol. 82, no. 3, pp. 465-473, 1968.

[23] A. Sandmo, "The effect of uncertainty on saving decisions," Review of Economic Studies, vol. 37, no. 3, pp. 353-360, 1970.

[24] J. H. Dreze, "Consumption decisions under uncertainty," Journal of Economic Theory, vol. 5, no. 3, pp. 308-335, 1972.

[25] S. P. Zeldes, "Optimal consumption with stochastic income: deviations from certainty equivalence," Quarterly Journal of Economics, vol. 104, no. 2, pp. 275-298, 1989.

[26] S. P. Zeldes, "Consumption and liquidity constraints: an empirical investigation," Journal of Political Economy, vol. 97, no. 2, pp. 305-346, 1989.

[27] A. Deaton, "Saving and liquidity constraints," Econometrica, vol. 59, no. 5, pp. 1221-1248, 1991.

[28] C. D. Carroll, "Buffer-stock saving and the life cycle/permanent income hypothesis," Quarterly Journal of Economics, vol. 112, no. 1, pp. 1-55, 1997.

[29] P. O. Gourinchas and J. A. Parker, "Consumption over the life cycle," National Bureau of Economic Research Working Paper 7271, 1999.

[30] P. O. Gourinchas and J. A. Parker, "The empirical importance of precautionary savings," National Bureau of Economic Research Working Paper 8107, 2001.

[31] C. Lee, "Life-cycle saving in the United States, 1900-90," Review of Income and Wealth, vol. 47, no. 2, pp. 165-179, 2001.

[32] J. C. H. Emery, "From defining characteristic to vitiation of principle: the history of the IOOF's sick benefit and its implications for studying American fraternalism," Social Science History, vol. 30, no. 4, pp. 479-500, 2006.

[33] R. J. Gordon, Macroeconomics, Addison Wesley, Boston, Mass, USA, 9th edition, 2003.

[34] R. Aiyagari, "Uninsured idiosyncratic risk and aggregate saving," Quarterly Journal of Economics, vol. 109, no. 3, pp. 659684, 1994.

[35] T. F. Cooley and J. Soares, "Privatizing social security," Review of Economic Dynamics, vol. 2, pp. 731-755, 1999.

[36] M. Huggett, "Wealth distribution in life-cycle economies," Journal of Monetary Economics, vol. 38, no. 3, pp. 469-494, 1996.

[37] S. Wilson, "A dynamic general equilibrium analysis of migration and capital formation: the case of Canada," Review of Economic Dynamics, vol. 6, no. 2, pp. 455-481, 2003.
[38] X. Mateos-Planas, "The demographic transition in Europe: a neoclassical dynastic approach," Review of Economic Dynamics, vol. 5, no. 3, pp. 646-680, 2002.

[39] J. A. Doornik, Object-Oriented Matrix Programming Using Ox, Timberlake Consultants Press and Oxford, London, UK, 3rd edition, 2002.

[40] J. E. Murray, Origins of American Health Insurance: A History of Industrial Sickness Funds, Yale University Press, New Haven, Conn, USA, 2007. 


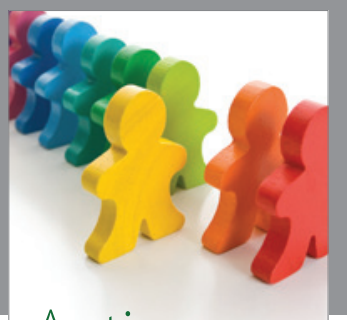

Autism

Research and Treatment
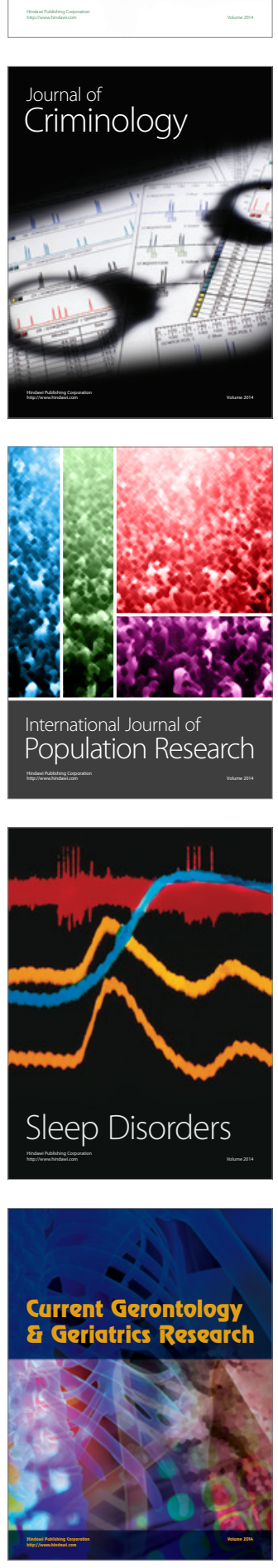
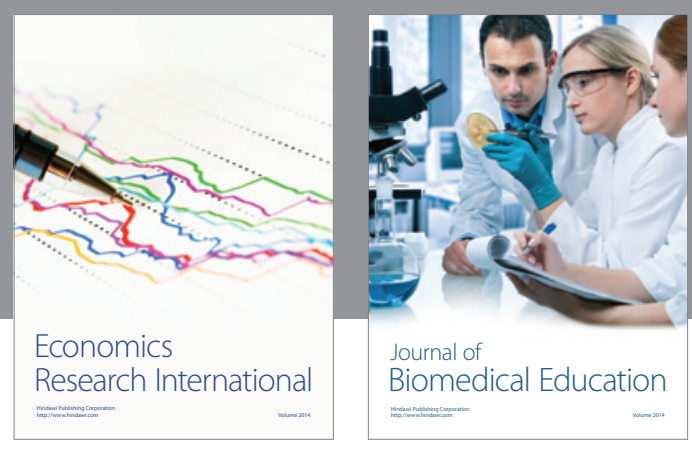

Journal of

Biomedical Education

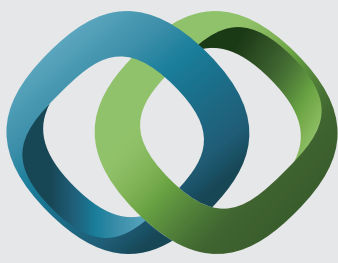

\section{Hindawi}

Submit your manuscripts at

http://www.hindawi.com
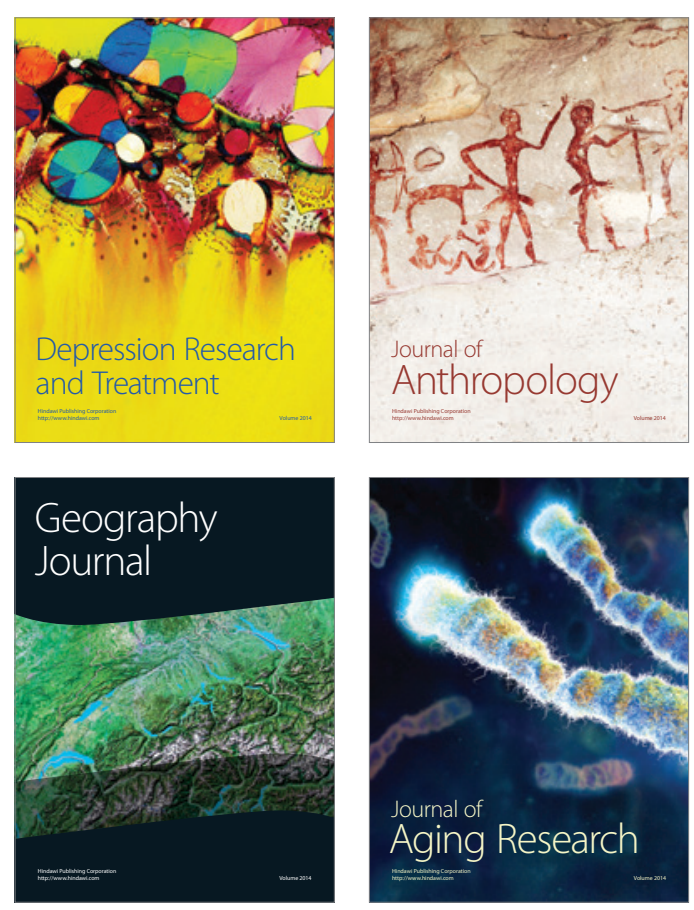

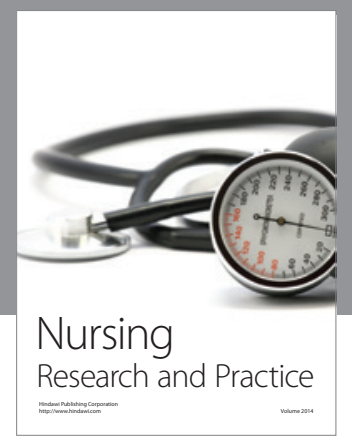

Nursing

Research and Practice

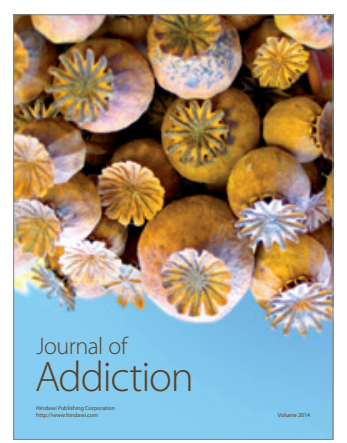

Child Development

Research

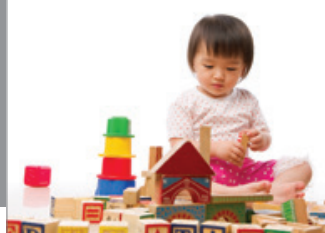

迥
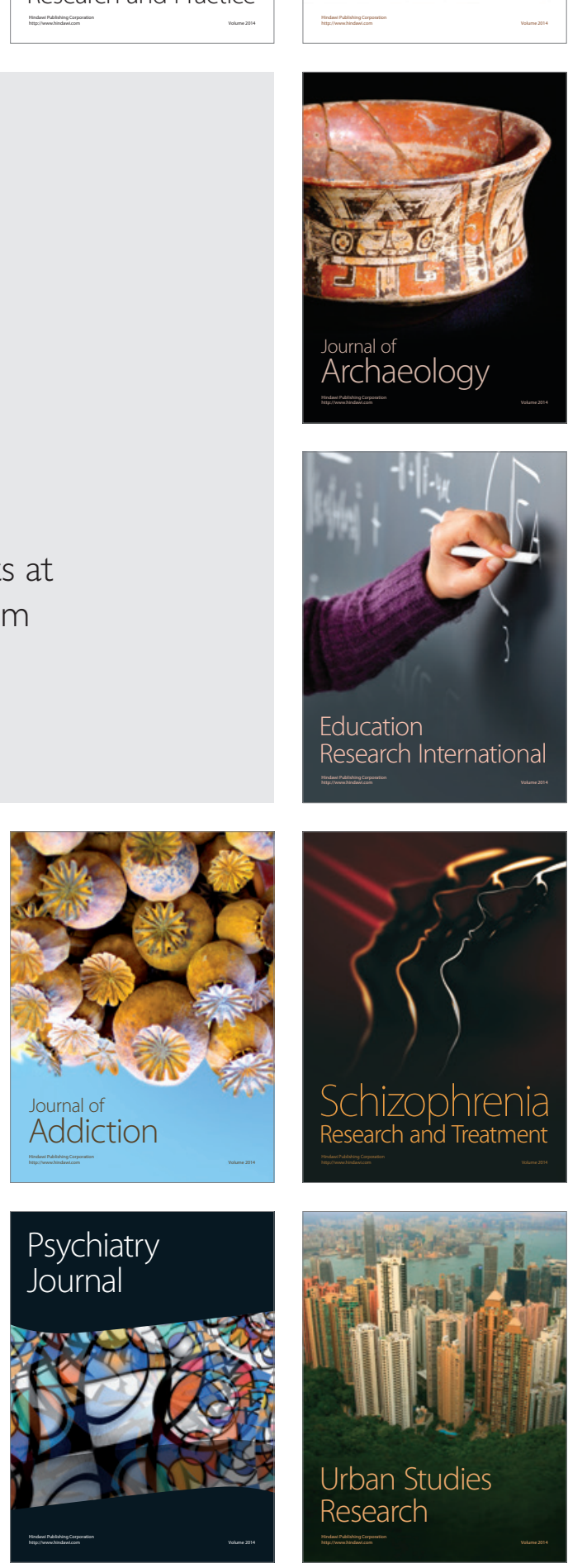